Izabela Zawiślińska

\title{
PAŃSTWO WE WSPÓŁCZESNEJ GOSPODARCE ŚWIATOWEJ - WYBRANE ZAGADNIENIA
}

\section{Wprowadzenie}

Państwo jest podstawowym podmiotem stosunków międzynarodowych i odgrywa kluczową rolę w kształtowaniu relacji oraz powiązań gospodarczych w skali globalnej. Przed kryzysem ekonomicznym 2007+ przez kilka dekad dominowała doktryna głosząca kres pozycji i znaczenia państwa w gospodarce zarówno w wymiarze wewnętrznym, jak i międzynarodowym. To rynek i jego mechanizm miał być optymalnym instrumentem przywracania oraz utrzymywania równowagi wewnętrznej i zewnętrznej. Wierzono, że rynki zdolne są do samoregulacji, że są stabilne, trwałe i że zawsze można na nich polegać. Natomiast państwo i jego instytucje postrzegane były jako czynniki ograniczające działanie mechanizmu rynkowego, jak również utrudniające działanie pozapaństwowych podmiotów w gospodarce światowej. Argumentowano, że nadmiar regulacji jest powodem zaburzeń i kryzysów w gospodarce, a wprowadzanie kolejnych może jedynie spowodować, że następne kryzysy będą jeszcze groźniejsze.

Odbywająca się w tym duchu w wielu państwach postępująca liberalizacja i deregulacja wielu sektorów - głównie finansowego, w połączeniu z pojawianiem się innowacji w instrumentach wykorzystywanych przez rynek finansowy, zamiast do zwiększenia poziomu dobrobytu poszczególnych podmiotów i ograniczania nierównowagi w skali mikro- i makroekonomicznej, doprowadziła do wybuchu kryzysu finansowego, który następnie przeniósł się do realnej sfery gospodarek na skalę niespotykaną od czasów wielkiego kryzysu przełomu lat 20. i 30. XX wieku1. $\mathrm{W}$ takich okolicznościach zarówno przedsiębiorstwa z różnych branż - a w pierwszej kolejności instytucje finansowe - jak również inne pozapaństwowe podmioty gospodarki światowej, uznając swoją bezradność w walce z kryzysem, zwracały się o pomoc i wsparcie do państwa i jego instytucji. Jednocześnie, gdy ich sytuacja

${ }^{1}$ Ponadto, podobnie jak wielki kryzys początku XX wieku, odbił się on również na sytuacji w finansach publicznych wielu państw, w tym także rozwiniętych, które przez ostatnie dziesięciolecia postrzegane były za filar stabilizujący całą współczesną gospodarkę światową. 
w wyniku wsparcia środkami publicznymi uległa poprawie lub gdy zdały sobie sprawę, że są za duże i za ważne, aby upaść, a tym samym pomoc ze strony państwa jest pewnikiem, ponownie głoszą krytyczne opinie o roli państwa w gospodarce na szczeblu narodowym i globalnym. Co więcej, nie unikają także krytycznych opinii w kwestii działań podejmowanych $\mathrm{w}$ walce $\mathrm{z}$ kryzysem, a przede wszystkim negatywnie oceniają sytuację w finansach publicznych wielu państw, zapominając, że w dużej mierze, jeśli to nie one wywołały te trudności, to przynajmniej się do nich w dużym stopniu przyczyniły. Wydaje się więc, że w warunkach dobrej koniunktury gospodarczej i stabilnych perspektyw co do przyszłości większość podmiotów gospodarczych dąży do ograniczania pozycji i znaczenia państwa.

Podejmowane są różne wysiłki na rzecz zmniejszenia funkcji kontrolnych, regulacyjnych, fiskalnych i redystrybucyjnych. Postawy te można byłoby zrozumieć, gdyby cechowała je konsekwencja. Tak więc gdyby w okresach złej koniunktury, w warunkach pogarszających się wyników podmiotów gospodarczych nie oczekiwały one interwencji i pomocy ze strony państwa. Tymczasem kryzys finansowy czy gospodarczy automatycznie uruchamia roszczenia pomocowe od państwa i jego instytucji. Niejednokrotnie zdarza się, że następstwa indywidualnych egoistycznych decyzji podmiotów gospodarczych musi ponosić i finansować państwo, a tym samym wszyscy jego obywatele, czyli podatnicy. Tak było i również jest tym razem, co wzbudza coraz powszechniejszy sprzeciw społeczny. Jednak w odróżnieniu od wielu poprzednich kryzysów gospodarczych, z jakimi zetknęły się gospodarki w XIX czy XX wieku, które także miały światowy zasięg ${ }^{2}$, działania o wewnętrznym charakterze nie były wystarczające, a w wielu przypadkach wykraczały poza możliwości finansowe pojedynczych państw. Konieczna okazała się współpraca międzynarodowa państw, skoordynowana z działaniami organizacji międzynarodowych o międzyrządowym charakterze, która na nowo definiuje pozycję państwa i jego instytucji w XXI wieku. Można jednak zadać sobie pytanie: czy bez doktrynalnych zmian w teoretycznych koncepcjach międzynarodowego ładu gospodarczego tworzenie kolejnych instytucji o międzyrządowym charakterze będzie skutecznym rozwiązaniem?

2 Przykładowo kryzys z 1825 r. zainicjowany w Wielkiej Brytanii i związany z bańką spekulacyjną na rynku akcji i obligacji dotyczących inwestycji w nowy rynek niepodległego Peru, następnie kryzys z $1857 \mathrm{r}$. będący następstwem spekulacji w handlu niewolnikami, w branży kolejowej, instrumentach finansowych i sprzedaży ziemi zainicjowanej w USA, kryzys z 1873 r. związany ze spekulacją w sieci kolei żelaznej w USA i Ameryce Łacińskiej, kryzys z 1907 r. rozpętany w Stanach Zjednoczonych po pęknięciu bańki spekulacyjnej na giełdach i rynku nieruchomości. Por: N. Roubini, S. Mihm, Ekonomia kryzysu, przeł. R. Mitoraj, Wolters Kluwer Polska, Warszawa 2011, s. 40-42. 


\section{Zaangażowanie rządów i banków centralnych}

W obliczu narastających zjawisk kryzysowych w 2007 i 2008 roku instytucje finansowe, $\mathrm{w}$ tym głównie banki, jak również przedsiębiorstwa $\mathrm{z}$ innych branż, zwracały się o pomoc do państwa i oczekiwały jej na znaczącym poziomie. Niepokojące dane dotyczące perspektyw rozwojowych dostarczały zarówno instytucje statystyczne i prognostyczne poszczególnych państw, jak i instytucje międzynarodowe. Przykładowo, jak wynika z danych zawartych w tabeli 1, Organizacja Współpracy Gospodarczej i Rozwoju przewidywała, że w wyniku kryzysu finansowego załamanie gospodarcze dotknie wszystkie państwa - spadek światowego PKB o 1,3\% - jednak w różnym stopniu. W połowie 2009 r. prognozowano, że w dużo większym stopniu negatywnie odbije się ono na gospodarkach państw rozwiniętych - ujemny wzrost gospodarczy o 3,8\%, podczas gdy gospodarki państw rozwijających się miały odczuć spowolnienie do $1,6 \% \mathrm{w}$ skali roku.

Tabela 1. Główne wskaźniki makroekonomiczne w latach 2007-2009

\begin{tabular}{|c|c|c|c|c|}
\hline & 2007 & 2008 & $2009^{a}$ & $2009^{b}$ \\
\hline \multicolumn{5}{|l|}{ Dynamika PKB w \% } \\
\hline Świat & 5,2 & 3,2 & $-1,3$ & $-0,7$ \\
\hline Państwa rozwinięte & 2,7 & 0,9 & $-3,8$ & $-3,7$ \\
\hline Państwa rozwijające się & 8,3 & 6,1 & 1,6 & 2,8 \\
\hline \multicolumn{5}{|c|}{ Handel towarami i usługami - zmiana w \% } \\
\hline Świat & 7,2 & 3,3 & $-11,0$ & $-10,7$ \\
\hline \multicolumn{5}{|c|}{ Import towarów i usług - zmiana w \% } \\
\hline Państwa rozwinięte & 4,7 & 0,4 & $-12,1$ & $-12,2$ \\
\hline Państwa rozwijające się & 14,0 & 10,9 & $-8,8$ & $-8,0$ \\
\hline \multicolumn{5}{|c|}{ Eksport towarów i usług - zmiana w \% } \\
\hline Państwa rozwinięte & 6,1 & 1,8 & $-13,5$ & $-11,9$ \\
\hline Państwa rozwijające sie & 9,5 & 6,0 & $-6,4$ & -77 \\
\hline
\end{tabular}

a prognoza

Źródło: World Economic and Financial Surveys IMF, World Economic Outlook: crisis and recovery, April 2009, s. 10 .

b prognoza

Źródło: World Economic and Financial Surveys IMF, World Economic Outlook: slowing growth, rising risks, September 2011. 
Także Międzynarodowy Fundusz Walutowy przewidywał, że ujemna dynamika zmian PKB w skali globalnej będzie spowodowana załamaniem gospodarek rozwiniętych (spadek o 3,9\% w 2009 r.) i spowolnieniem dynamiki wzrostowej w państwach rozwijających się (wzrost w 2009 r. o 1,6\% w porównaniu do 6,2\% w 2008 r. i 8,3\% w 2007 r.) $)^{3}$. Opublikowane w czerwcu 2009 r. prognozy OECD potwierdzały zarówno kierunek, jak i skalę zmian przedstawionych przez Międzynarodowy Fundusz Walutowy. Szacowano w owym czasie, że gospodarki państw OECD skurczą się w 2009 r. średnio o 4,1\%, by w 2010 r. zanotować $0,7 \%$ wzrost $^{4}$.

W celu łagodzenia skutków światowego kryzysu finansowego i gospodarczego państwo i jego instytucje ponownie musiały się uaktywnić. Rządy większości państw współczesnej gospodarki światowej dotkniętych tym załamaniem podjęły działania z zakresu polityki fiskalnej, stanowiące element większych pakietów antykryzysowych. Działania fiskalne były uzupełniane przez interwencje oraz różne instrumenty stosowane przez banki centralne. Skala ekspansji fiskalnej, rozumianej jako obniżenie podatków lub zwiększenie wydatków budżetowych, miała charakter bezprecedensowy. W ciągu pierwszych kilku miesięcy kryzysu członkowie G-20 przyjęli pakiety fiskalne o wartości blisko 2 bln dol. Zdecydowana większość tej kwoty została przeznaczona na dokapitalizowanie sektora bankowego w celu podniesienia płynności finansowej oraz przywrócenia akcji kredytowej. Niestety, tylko część wydatków związana była $\mathrm{z}$ tworzeniem nowych miejsc pracy oraz utrzymaniem już istniejących - głównie projekty infrastrukturalne, jak również w sferze socjalnej.

W Stanach Zjednoczonych rząd prowadził działania, które z jednej strony miały przyczynić się do ustabilizowania sytuacji w systemie finansowym, a $\mathrm{z}$ drugiej - przeciwdziałać załamaniu w realnej sferze gospodarczej. W tym pierwszym obszarze rząd wprowadził kompleksowy plan stabilności finansowej (financial stability plan), który był uzupełniany nowymi instrumentami dostosowanymi, jak się wydawało, do okoliczności i potrzeb rynku finansowego ${ }^{5}$. Co ciekawe, programy były przygotowywane przez osoby, które albo $\mathrm{w}$ tamtym czasie, albo w przeszłości powiązane były silnie $\mathrm{z}$ instytucjami finansowymi i, co pokazała przyszłość, działały na rzecz ograniczenia strat sektora finansowego kosztem sytuacji w finansach publicznych i realnej sferze gospodarki, mimo że były funkcjonariuszami publicznymi. Drugim obszarem działania były inicjatywy przeciwdziałające załamaniu w realnej sferze gospodarki. W tym celu przykładowo w styczniu 2008 r. w Stanach Zjednoczonych

\footnotetext{
3 World Economic and Financial Surveys IMF, World Economic Outlook: crisis and recovery, April 2009, s. 10.

${ }^{4}$ OECD, Economic Outlook, June 2009, no. 85, s. 9.

3 października 2008 r. Kongres USA zatwierdził plan ratowania banków na kwotę 700 mld dol. Por. „Gazeta Wyborcza” 2011, 12 września, s. 24-25.
} 
przyjęto pakiet cięć podatkowych dla osób fizycznych i przedsiębiorstw o łącznej wartości 152 mld dol. ${ }^{6}$ Co szczególnie istotne, w głównej mierze skierowany był on do wąskiego grona osób fizycznych i prawnych z grupy najwięcej zarabiających. Klasa średnia i najubożsi prawie nie odczuli zmian podatkowych. Jednak już samo porównanie kwot przeznaczonych w początkowej fazie kryzysu na pakiety pomocowe pokazuje skalę asymetrii pomocy, a tym samym odzwierciedla siłę różnych grup interesów. Kolejna ustawa z lutego 2009 r. American recovery and reinvestment act opiewała na kwotę 787 mld dol. Zakładano w niej zestaw instrumentów, począwszy od wydatków państwa na zakup towarów i usług, projekty infrastrukturalne, m.in. w energetyce ${ }^{7}$, rybołówstwie, kontroli żywności, jak również ulgi podatkowe ${ }^{8}$ i płatności transferowe. Na pakiet ten należy patrzeć przez pryzmat utrzymywania wysokiego wsparcia sektora finansowego. O skali pomocy mogą świadczyć obliczenia agencji Bloomberg, z których wynika, że fundusze na walkę z kryzysem, jakie wydały, pożyczyły lub wydzieliły rząd USA i FED, sięgnęły blisko 12,8 bln dol. Kwota ta jest nieznacznie niższa od nominalnego amerykańskiego PKB, który w 2008 r. wyniósł 14,2 bln dol. Najwięcej na walkę z kryzysem przeznaczył FED.

Działania pomocowe zarówno dla sektora finansowego, jak i realnej sfery gospodarki podejmowane były także w innych państwach, w tym w Unii Europejskiej. Łączna pomoc publiczna zatwierdzona przez Komisję Europejską i skierowana tylko do sektora finansowego do połowy 2009 r. wyniosła 3 319,7 mld euro. Największe programy gwarancji w ujęciu bezwzględnym wdrożyły Dania, Niemcy, Irlandia, Wielka Brytania i Francja - powyżej 250 mld euro. W ramach Unii Europejskiej przyjęty został także jesienią 2008 r. europejski plan naprawy gospodarczej, który przewidywał przeznaczenie na różne projekty rozwojowe kwotę 200 mld euro 9 . Ponadto poszczególne państwa członkowskie realizowały własne programy ożywiania gospodarki. W szczególności adresowano je do najbardziej dotkniętych w początkowej fazie kryzysu sektorów gospodarki, np. budownictwa czy przemysłu samochodowego.

Pakiety o fiskalnym charakterze przyjmowano także w innych państwach w różnych częściach świata, np. w Kanadzie, Australii, Korei Południowej czy Indiach. Japonia uruchomiła program obniżek podatków i zwiększonych wydatków, choć jego skala - głównie ze względu na problemy polityczne - nie miała zbyt ambitnego charakteru. Odmiennie postąpiły Chiny, które w obawie przez znaczącym

\footnotetext{
6 Por. N. Roubini, S. Mihm, Ekonomia kryzysu..., op.cit., s. 191.

7 Zakładano, że wydatki na infrastrukturę i projekty energetyczne miały wynieść 140 mld dol. Patrz za: www.recovery.gov/Pages/home.aspx, a także N. Roubini, S. Mihm, Ekonomia kryzysu..., op.cit., s. 192.

8 Łączna wartość ulg podatkowych skierowanych do osób fizycznych mała wynieść 237 mld dol. Patrz za: www.recovery.gov/Pages/home.aspx oraz N. Roubini, S. Mihm, Ekonomia kryzysu..., op.cit., s. 192.

9 Por. N. Roubini, S. Mihm, Ekonomia kryzysu..., op.cit., s. 192.
} 
spowolnieniem gospodarki zdecydowały się na wprowadzenie pakietu fiskalnego wartego $586 \mathrm{mld}$ dol. Zasadniczym elementem tego planu były wydatki na roboty publiczne związane z budową linii kolejowych, dróg, systemów nawadniających i lotnisk ${ }^{10}$.

W pomoc gospodarce, ale przede wszystkimi instytucjom rynku finansowego, obok rządów, zaangażowały się także banki centralne. W obliczu gwałtownego załamania podaży kapitału banki centralne stanęły wobec konieczności zapewnienia płynności oraz zwiększonej dbałości o wzrost gospodarczy ${ }^{11}$. Działania te sprowadzały się do:

- szybkiego i głębokiego cięcia stóp procentowych;

- zasilenia banków komercyjnych płynnością;

- ilościowego poluzowania polityki pieniężnej (quantitative easing);

- deklaracji i działań na rzecz osłabienia walut krajowych (Szwajcaria, Wielka Brytania, Stany Zjednoczone, Norwegia).

W krótkim okresie podejmowane przez banki centralne działania były konieczne dla podtrzymania płynności w systemach finansowych i przeciwdziałania gwałtownemu załamaniu produkcji, handlu i inwestycji. Jednak należy podkreślić, że reakcja na kryzys przybrała postać działań, które wcześniej w dużej mierze doprowadziły do jego wygenerowania. Sprowadzały się one bowiem do wpompowania płynności do systemu finansowego i obniżenia stóp procentowych w skali całego międzynarodowego systemu finansowego. Ponadto problem był związany z brakiem zaufania między instytucjami finansowymi i innymi podmiotami, co prowadziło do kuriozalnych sytuacji, w których dostarczana przez banki centralne płynność do systemu finansowego nie była przeznaczana na odbudowę i rozwój akcji kredytowej, lecz wracała do banków centralnych w postaci depozytów lub zakupu bonów pieniężnych.

Wszystkie opisane powyżej działania miały doprowadzić do zahamowania tendencji recesyjnych, ożywienia realnej gospodarki i handlu międzynarodowego, jak również do uzyskania stabilizacji międzynarodowych przepływów kapitałowych. Jak się jednak szybko okazało, skutki pakietów pomocowych o charakterze fiskalnym i pieniężnym nie miały długofalowego charakteru, a ich skala była relatywnie niewielka, szczególnie w obrębie państw rozwiniętych. Wynikało to $\mathrm{z}$ faktu, iż w sytuacji kryzysowej, poczucia zagrożenia i niepewności co do przyszłości podmioty gospodarcze - zarówno przedsiębiorstwa, jak i gospodarstwa domowe

\footnotetext{
${ }^{10}$ Ibidem.

11 O skali problemów wynikających z zamrożenia rynku międzybankowego może świadczyć fakt, że już 9 sierpnia 2007 r. Europejski Bank Centralny pożyczył 94 mld euro około pięćdziesięciu bankom. Następnego dnia na podobny cel przeznaczył kwotę 61 mld euro. Także System Rezerwy Federalnej udzielił analogicznej pomocy na kwotę 60 mld dol. w ciągu dwóch dni. Por. ibidem, s. 123.
} 
- w ograniczonym stopniu przeznaczały uzyskane środki na dodatkową konsumpcję i inwestycje. Można było odnotowywać wzrost krańcowej skłonności do oszczędzania, przy osłabieniu presji inwestycyjnej. Jak pokazały badania przeprowadzone w USA, z każdego dodatkowego dolara podmioty gospodarcze wydatkowały jedynie 25-30 centów. Reszta była przechowywana jako zabezpieczenie na niepewną przyszłość. Oznaczało to uruchomienie tzw. efektów mnożnikowych, jednak na skalę dużo mniejszą niż oczekiwały władze uruchamiające pakiety pomocowe. Jednocześnie w wyniku znacznie słabszych bodźców wyjściowych same procesy mnożnikowe także wygasały szybciej niż sądzono.

Stabilność systemu finansowego jest czynnikiem niezbędnym do sprawnego funkcjonowania każdej gospodarki w różnych jej wymiarach. Dlatego też koncentrowanie pomocy na ustabilizowaniu sytuacji na rynkach finansowych wydawało się uzasadnione, tym bardziej, że ich problemy były szczególnie nagłaśniane. Niestety okazało się, że pomoc dla sektora uzasadniona jest tylko wówczas, gdy instytucje finansowe będą działać zgodnie ze statusem podmiotu zaufania publicznego. Tymczasem tylko w najtrudniejszym momencie były one gotowe rzetelnie przyjąć na siebie taką funkcję, a po uzyskaniu gwarancji i pomocy ponownie powróciły do swoich zachowań i zwyczajów typowych dla okresu poprzedzającego krach na rynkach finansowych. Oznaczało to więc, że część środków z pakietów pomocowych została przeznaczona na wysokie premie dla pracowników sektora finansowego, ograniczając tym samym zarówno akcję kredytową, jak i same efekty mnożnikowe.

Ograniczona skuteczność działań pomocowych podejmowanych przez władze fiskalne i pieniężne poszczególnych państw w dużej mierze wynikała także $\mathrm{z}$ faktu, że w głównych gospodarkach dotkniętych kryzysem skala problemów, a także polityczne i gospodarcze powiązania między państwami, połączona z międzynarodową kooperacją na szczeblu pozapaństwowym, sprawiły, że poszczególne państwa nie były w stanie samodzielnie poradzić sobie z zaistniałą sytuacją. Potwierdza to tzw. druga fala zjawisk kryzysowych, powiązana $\mathrm{z}$ „reaktywacją” kryzysu zadłużeniowego. Dlatego też niezbędna stała się bardziej zaawansowana współpraca międzynarodowa państw i ich instytucji w wielu obszarach w miejsce tradycyjnej konsultacji i niezobowiązującej koordynacji. Ponadto narastanie zjawisk kryzysowych przyczynia się do eskalacji niezadowolenia w społeczeństwach państw rozwiniętych. Zapewne będzie to miało wpływ na projekty w ramach prowadzonych polityk gospodarczych także o międzynarodowym charakterze. 


\section{Współpraca międzynarodowa państw w walce z kryzysem - wybrane przykłady}

\subsection{G20 i jej inicjatywy}

Rosnąca częstotliwość występowania kryzysów ekonomicznych w gospodarce światowej, połączona $\mathrm{z}$ coraz większą intensywnością ich negatywnych skutków odczuwanych w gospodarkach o różnym poziomie rozwoju ekonomicznego, jak również $\mathrm{w}$ różnych regionach świata, doprowadziła do powstania nowego forum konsultacji, współpracy i inicjatyw. Zasadniczą przesłanką sfinalizowania przedsięwzięcia G20 była zmiana, jaka dokonuje się w podmiotowej strukturze współczesnej gospodarki światowej, wynikająca z modyfikacji przepływów handlowych i kapitałowych oraz potencjału ekonomicznego poszczególnych gospodarek. Istotne było także przeświadczenie, że postępująca liberalizacja, szczególnie w sferze przepływów kapitałowych, jak również narastające nierównowagi globalne mogą doprowadzić do trudnych sytuacji, którym dotychczasowe gremium G7 czy G8 nie będzie w stanie sprostać ${ }^{12}$.

Członkami G20 są ministrowie finansów i szefowie banków centralnych 19 państw, choć spotkania obywają się także na szczeblu szefów rządów i głów państw ${ }^{13}$. Unia Europejska, reprezentowana przez rotacyjnego przewodniczącego Rady i prezesa EBC, jest dwudziestym członkiem grupy. Nieoficjalnymi uczestnikami spotkań G20 są przedstawiciele najwyższego szczebla Międzynarodowego Funduszu Walutowego i Banku Światowego. Ma to zagwarantować lepszą współpracę i spójność podejmowanych działań na szczeblu głównych gospodarek i organizacji międzyrządowych o globalnym zasięgu, kluczowych dla funkcjonowania i stabilności międzynarodowego ładu gospodarczego. Bardzo częstym argumentem, który ma legitymizować funkcjonowanie grupy G20, jest potencjał podmiotów w nim uczestniczących, połączony z różnorodnością geograficzną. Na wszystkich uczestników grupy przypada około 90\% światowego PKB, 80\% światowego handlu - w tym handlu wewnętrznego na obszarze UE - i 2/3 światowej populacji ${ }^{14}$.

\footnotetext{
12 Jak na razie to nowe gremium także nie jest w stanie im sprostać. Ograniczoność implementacji ustaleń, konflikty interesów, wciąż narastająca skala problemów bez rzetelnej i wiarygodnej oceny sytuacji to tylko przykłady uwarunkowań wpływających na bieżącą ocenę.

13 Argentyny, Australii, Brazylii, Kanady, Chin, Francji, Niemiec, Indii, Indonezji, Włoch, Japonii, Meksyku, Rosji, Arabii Saudyjskiej, RPA, Korei Południowej, Turcji, Wielkiej Brytanii i USA.

14 Za: www.g20.org (dostęp: 25 sierpnia 2011 r.).
} 
Przedsięwzięcie G20 miało stanowić międzynarodowe gremium na najwyższym szczeblu, które m.in. poprzez ścisłą współpracę z kluczowymi organizacjami międzynarodowymi będzie posiadało taką gamę informacji o sytuacji w gospodarce światowej i kierunkach zmian, jakie w niej zachodzą, że będzie w stanie ostrzegać społeczność międzynarodową o potencjalnych zagrożeniach. Oczekiwano również, że dzięki zaangażowaniu kluczowych dla współczesnej gospodarki światowej podmiotów państwowych i ponadpaństwowych wypracowane zostaną mechanizmy, które potencjalne sytuacje kryzysowe będą ograniczać lub im przeciwdziałać. Panowało także przekonanie, że w rozszerzonym gronie uda się wypracować spójne programy wdrażane przez wiodące gospodarki, nakierowane na ożywienie ekonomiczne państw dotkniętych kryzysem lat 90. XX wieku. Jak pokazały kolejne lata, przeświadczenie to było złudne. Współpraca i forum dyskusji, jakim jest G20, nie stanowi wystarczającej gwarancji stabilności zarówno międzynarodowego systemu finansowego, jak i realnej sfery gospodarek. Aktywność pozapaństwowych podmiotów gospodarki światowej kierujących się ideą zysku za wszelką cenę, w połączeniu $\mathrm{z}$ daleko posuniętą deregulacją rynków finansowych, powoduje, że próby działań podejmowane także na forum G20 okazały się nieskuteczne. Ponadto w sytuacjach kryzysowych organizm o charakterze konsultacyjnym i koordynacyjnym ma ograniczone możliwości działania. Może bowiem jedynie przyjmować różne rezolucje, opracowywać zalecenia i sugerować konkretne działania lub próbować je koordynować. Jednak wszystkie one mają jedynie deskryptywny charakter. Nie mają mocy wiążącej zarówno dla samych członków G20, jak i innych państw czy organizacji międzynarodowych. Na to wszystko nakłada się standardowe egoistyczne zachowanie koncentrujące się w sytuacjach zagrożenia na ochronie własnych interesów i przeciwdziałaniu wewnętrznym zjawiskom kryzysowym. Wydarzenia ostatnich lat tylko pozornie zmieniły te odczucia.

Tak więc należy oczywiście pamiętać, że G20 od początku swojego istnienia podejmowała różne inicjatywy ukierunkowane na poprawę jakości środowiska, w jakim przychodzi funkcjonować uczestnikom gospodarki światowej. Można tu przytoczyć inicjatywę nowych i wyższych standardów przejrzystości i wymiany informacji $\mathrm{w}$ sprawach podatkowych, zacieśnienia kooperacji międzynarodowej, podejmowanie działań na rzecz przeciwdziałania zjawiskom kryzysowym poprzez ograniczanie luki informacyjnej między państwami, zachęcania do reform strukturalnych Międzynarodowego Funduszu Walutowego i Banku Światowego, jak również koordynacji działań w ramach G20, m.in. w obszarze reform strukturalnych rynków 
towarów, usług i pracy ${ }^{15}$. Istotnym przedsięwzięciem wydaje się także próba ożywienia handlu międzynarodowego ${ }^{16}$ oraz powołanie Rady Stabilności Finansowej ${ }^{17}$ (FSB), która zastąpiła istniejące od 1999 r. Forum Stabilności Finansowej. Jednak, jak pokazują doświadczenia ostatnich kilkunastu miesięcy, o ile panuje konsensus w określaniu celów podejmowanych działań, to nie ma już go w odniesieniu do zestawu stosowanych narzędzi. Np. podczas szczytu G20 w dniach 26-27 czerwca 2010 r. w Toronto jego uczestnicy zgodzili się, że dla trwałego wprowadzenia gospodarek na ścieżkę ożywienia gospodarczego niezbędna jest ściślejsza współpraca największych gospodarek. Jednak już w obszarze metod, zakresu i tempa pewnych reform pozostają istotne różnice zdań. Udało się przeforsować wspólne stanowisko o konieczności łączenia pobudzania koniunktury z naprawą finansów publicznych ${ }^{18}$.

15 Ten ostatni element został przyjęty podczas szczytu we wrześniu 2009 r. w Pitsburgu w postaci dokumentu Ramy silnego, trwałego i zrównoważonego wzrostu.

16 Kryzys gospodarczy $2007+$, oprócz spadku globalnego PKB przełożył się także na zahamowanie wzrostowych tendencji $\mathrm{w}$ handlu międzynarodowym. Było to $\mathrm{z}$ jednej strony spowodowane spadkiem dochodów podmiotów gospodarczych lub pogorszeniem perspektyw sytuacji finansowej w przyszłości, co z kolei przełożyło się na wydatki konsumpcyjne i inwestycyjne, zaś z drugiej - wprowadzaniem nowych barier w handlu między państwami i ugrupowaniami integracyjnymi. Według analiz Banku Światowego od szczytu G20 w Waszyngtonie w 2008 r. wprowadzono na świecie 47 nowych narzędzi negatywnie wpływających na warunki handlu międzynarodowego. Najważniejsze z nich to subsydia w ramach przyjętych pakietów fiskalnych (m.in. wsparcie w wysokości ok. 48 mld dla przemysłu samochodowego, subsydia UE do eksportu masła, sera i mleka w proszku) i cła importowe (np. cła w Rosji na używane samochody, nowe cła Ekwadoru na ponad 600 towarów). Wobec pojawiania się nowych inicjatyw protekcjonistycznych konieczne było zapewnienie, że działania $\mathrm{w}$ walce $\mathrm{z}$ kryzysem nie przyczynią do wprowadzenia nowych barier dla handlu i inwestycji. Dlatego też przywódcy G20 zobowiązali się do ograniczenia negatywnych skutków podejmowanych działań dla swobody i warunków przepływu towarów, usług i kapitału oraz do informowania WTO o wprowadzanych nowych instrumentach mogących wywoływać takie skutki. Ponieważ jednym z rezultatów kryzysu są problemy $\mathrm{z}$ finansowaniem handlu, podjęto decyzję o wsparciu kwotą 250 mld dol. - za pośrednictwem międzynarodowych banków rozwoju - krajowych agencji kredytu eksportowego i inwestycji w celu przywrócenia dostępności kredytu dla przedsiębiorstw prowadzących działalność eksportową. Zobowiązano się również do postępu w negocjacjach WTO w ramach rundy z Doha. Por. A. Gradziuk, Plan G20 ożywienia i reform gospodarki światowej, „Biuletyn PISM” 2009, nr 19(551).

17 Przykładowo Rada Stabilności Finansowej przy współpracy z Międzynarodowym Funduszem Walutowym przygotowała strategię na rzecz stabilności finansowej, której głównym elementem jest szereg rekomendacji zawartych w raporcie Kryzys finansowy i luka informacyjna. Wskazuje się w nim m.in. na: potrzebę zwiększenia liczby państw zobowiązanych do składania sprawozdań z jakości zdrowia ich systemu finansowego, ograniczenie skali oaz podatkowych i konkurencji podatkowej, uściślenie metod pomiaru dźwigni finansowej i ryzyka walutowego skonsolidowanych pozycji zagranicznych, pobudzenie wymiany informacji o swapach i innych instrumentach pochodnych, zwiększenie informacji o systemowo ważnych instytucjach finansowych, gromadzenie danych o transgranicznej aktywności banków, w szczególności, gdy ich partnerami są instytucje finansowe, poprawienie jakości statystyk dotyczących sektora finansów publicznych, jak również na tworzeniu bazy danych dotyczących operacji na rynku nieruchomości. Należy jednak pamiętać, że realizacja powyższych zamierzeń będzie wymagać czasu i akceptacji ze strony uczestników międzynarodowych rynków finansowych. Rada Stabilności Finansowej nie ma bowiem realnych narzędzi pozwalających na egzekwowanie konkretnych zachowań czy regulacji.

18 Jeszcze podczas szczytu w Londynie 2 kwietnia 2009 r., w wyniku znacznie gorszych od oczekiwań danych makroekonomicznych, przedstawiono prognozy MFW wskazujące, że globalny PKB spadnie w 2009 r. o $0,5-1 \%$, natomiast WTO szacowało spadek światowego handlu na 9\%. Zadeklarowano wówczas 
Jednak zapis wskazujący na zobowiązanie się przez państwa rozwinięte do redukcji deficytu budżetowego o połowę do $2013 \mathrm{r}$. oraz do zmniejszenia lub przynajmniej ustabilizowania długu publicznego do 2016 r. został na wniosek USA uzupełniony stwierdzeniem, że konsolidacja fiskalna powinna być przyjazna dla wzrostu, a jej tempo należy dostosować do stanu przywracania wzrostu w różnych państwach ${ }^{19}$.

Partykularne interesy były także widoczne podczas posiedzenia 23 października 2010 r. w Gyeongju w Korei. Stany Zjednoczone wezwały najważniejsze państwa wysokorozwinięte do wprowadzenia 4-procentowego limitu wahań rachunku bieżącego bilansu płatniczego w stosunku do PKB. Inicjatywa ta została poparta m.in. przez Wielką Brytanię, Kanadę i Brazylię. Jednak Japonia i Niemcy sprzeciwiły się tej propozycji, a Chiny formalnie nie zabrały głosu w sprawie. Ostatecznie zadeklarowano jedynie wolę wzmocnienia współpracy rozwojowej w wymiarze zewnętrznym poprzez redukcję nadmiernej nierównowagi i utrzymanie nierównowagi bilansu płatniczego na zrównoważonym poziomie.

\subsection{Europejski System Nadzoru Finansowego}

Doświadczenia ostatniego kryzysu finansowego unaoczniły słabość działających instytucji kontrolnych i nadzorczych. Ograniczona skuteczność działań w szerszym gronie, jak również trudna sytuacja w sektorze finansowym i realnej gospodarce oraz finansach publicznych doprowadziły do tego, iż relatywnie szybko konkretne i skoordynowane działania w obszarze zmian w systemie nadzoru finansowego zostały podjęte w Unii Europejskiej. Z ich oceną należy jednak jeszcze poczekać, tym bardziej, że pewne próby zacieśniania współpracy w tym wymiarze były podejmowane także w przeszłości. Nie było jednak zgody na ograniczenie kompetencji nadzorczych na szczeblu narodowym i scedowanie ich na rzecz instytucji koordynującej działania na szczeblu unijnym ${ }^{20}$. Dopiero kryzys umożliwił, a w zasadzie wymusił na pań-

realizację planu ożywienia i reform, które miały m.in. pobudzić wzrost gospodarczy poprzez pakiety stymulacyjne. Zakładano dofinansowanie globalnych instytucji finansowych o 1,1 bln dol. i zwiększenie pakietów fiskalnych do 5 bln dol.

19 Por. A. Gradziuk, M. Koczor, Wyniki szczytu G20 w Toronto, „Biuletyn PISM” 2010, nr 100 (708).

20 Obowiązująca do końca 2010 r. struktura instytucji finansowych w UE została w głównej mierze utworzona zgodnie z zaleceniami raportu Lamfalussy’ego o reformie sektora papierów wartościowych. Zakładała ona czteropoziomową strategię integracji rynków finansowych, co przede wszystkim miało na celu poprawę koordynacji w zakresie stanowienia regulacji finansowych. Powołano także pewne podstawy instytucjonalne, w tym przede wszystkim Komitet Europejskich Nadzorów Rynków Papierów Wartościowych z siedzibą w Paryżu, Komitet Europejskich Nadzorów Ubezpieczeń i Emerytur Pracowniczych z siedzibą we Frankfurcie i Komitet Europejskich Organów Nadzoru Bankowego w Londynie. Były to tzw. komitety trzeciego poziomu, których głównym zadaniem była konwergencja praktyk nadzorczych poprzez wydawanie niewiążących wytycznych i rekomendacji oraz doradzanie Komisji Europejskiej w zakresie opracowywanych przez nią aktów prawnych. Jak czas pokazał, komitety te były niezdolne do zapewnienia bezpieczeństwa 
stwach członkowskich Unii Europejskiej porozumienie w sprawie dalszej integracji finansowej ${ }^{21}$. Jego konsekwencją jest obowiązujący od 1 stycznia 2011 roku Europejski System Nadzoru Finansowego.

Głównym celem nowego systemu jest zapewnienie właściwego wdrażania przepisów dotyczących sektora finansowego w sposób umożliwiający zachowanie stabilności finansowej i zapewnienie zaufania do systemu finansowego jako całości oraz odpowiedniej ochrony konsumentów usług finansowych. W skład Europejskiego Systemu Nadzoru Finansowego wchodzą:

- Europejska Rada ds. Ryzyka Systemowego (European Systemic Risk Board, ESRB);

- Europejskie Urzędy Nadzoru (European Supervisory Authorities, ESA)

- Europejski Urząd Nadzoru Bankowego (European Banking Authority, EBA)

- Europejski Urząd Nadzoru Ubezpieczeń i Pracowniczych Programów Emerytalnych (European Insurance and Occupational Pensions Authority, EIOPA)

- Europejski Urząd Nadzoru Giełd i Papierów Wartościowych (European Securities and Markets Authority, ESMA);

- Wspólny Komitet Europejskich Urzędów Nadzoru (Joint Committee);

- właściwe organy lub organy nadzoru państw członkowskich określone w odpowiednich aktach unijnych ${ }^{22}$.

finansowego. Dlatego też zostały, podobnie jak cały system, poddane masowej krytyce. Podkreślano przede wszystkim niewystarczające postępy w zakresie koordynacji działań implementacji i konwergencji standardów finansowych. Wśród przyczyn takiego stanu wskazywano głównie wąskie - przede wszystkim doradcze - kompetencje komitetów oraz niechętny stosunek instytucji krajowych. Mimo że Komisja Europejska wielokrotnie apelowała i podejmowała próby wzmocnienia mechanizmów kontrolnych, to wszystkie jej wcześniejsze inicjatywy były odrzucane przez państwa członkowskie. Sytuacja zmieniała się w następstwie skutków odczuwanych po ostatnim kryzysie 2007+ i ujawnieniu problemów instytucji finansowych, które naraziły na poważne straty nie tylko prywatnych uczestników rynku, ale też wiele państw; część z nich wręcz doprowadziły na skraj bankructwa. Dlatego też powołane w ramach nowych struktur instytucje mają docelowo szerszy zakres zadań i uprawnień. Por. www.knf.gov.pl (dostęp: 24 sierpnia 2011 r.).

21 Komisja Europejska zwróciła się do grupy kilku osób uznanych w świecie finansów o przygotowanie raportu na temat sytuacji i zagrożeń dla systemu finansowego. W sposób szczególny miał być rozpatrzony aspekt nadzoru finansowego ze wskazaniem konkretnych inicjatyw, także w wymiarze potencjalnych struktur instytucjonalnych, które powinny zostać ustanowione przez państwa członkowskie Unii Europejskiej dla zapewnienia bezpieczeństwa finansowego w przyszłości. Ostateczną wersję tzw. raportu Larosiere’a opublikowano 25 lutego $2009 \mathrm{r}$. Wskazano w nim jednoznacznie, że wyczerpała się dotychczasowa formuła współpracy na bazie konsultacyjno-koordynacyjnych komitetów trzeciego poziomu, a europejska stabilność finansowa wymaga ustanowienia silnych ponadnarodowych instytucji nadzoru. Jednocześnie podkreślono, że plan reformy sektora finansowego w Unii Europejskiej powinien zawierać procedury zarządzania kryzysowego. Zalecono również powołanie ciał nadzoru mikro- i makrofinansowego i wyposażenia ich w kompetencje regulacyjne. Następnie ustalenia zawarte w raporcie były przedmiotem dyskusji i negocjacji na forum najważniejszych instytucji Unii Europejskiej. Szczególne miejsce zajmowała w nich kwestia kompetencji i uprawnień organów nadzorczych w ramach nowego systemu. Ostatecznie kompromis udało się wypracować przez Parlament Europejski i Radę w dniach 2-3 września 2010 r.

22 Por. www.knf.gov.pl (dostęp: 24 sierpnia 2011 r.). 
W rozporządzeniu Parlamentu Europejskiego i Rady Unii Europejskiej nr 1092/2010 z dnia 24 listopada 2010 r. w sprawie unijnego nadzoru makroostrożnościowego nad systemem finansowym i ustanowienia Europejskiej Rady ds. Ryzyka Systemowego wskazano, że „ERRS jest odpowiedzialna za sprawowanie nadzoru makroostrożnościowego nad systemem finansowym w Unii w celu przyczyniania się do przeciwdziałania ryzykom systemowym dla stabilności finansowej w Unii, które pojawiają się w związku z wydarzeniami w obrębie systemu finansowego, lub ograniczania tych ryzyk, z uwzględnieniem zmian natury makroekonomicznej, tak aby zapobiegać okresom rozpowszechnionego występowania trudności finansowych. ERRS przyczynia się do sprawnego funkcjonowania rynku wewnętrznego i tym samym zapewnia trwały wkład sektora finansowego we wzrost gospodarczy"23.

Na strukturę organizacyjną Europejskiej Rady ds. Ryzyka Systemowego składają się: Rada Generalna, Komitet Sterujący, Sekretariat, Doradczy Komitet Naukowy i Doradczy Komitet Techniczny ${ }^{24}$. Przez okres pięciu lat po wejściu w życie rozporządzenia nr 1092/2010 Europejskiej Radzie ds. Ryzyka Systemowego przewodniczy prezes Europejskiego Banku Centralnego. Na kolejne kadencje wybór przewodniczącego ERRS ma być dokonywany zgodnie z zasadami określonymi w ramach przeglądu przewidzianego $\mathrm{w}$ art. 20 ust. 2. wspomnianego rozporządzenia.

Europejska Rada ds. Ryzyka Systemowego w przypadku zidentyfikowania znaczących ryzyk zagrażających osiągnięciu podstawowego celu wydaje ostrzeżenia oraz zalecenia w sprawie działań zaradczych, w tym w sprawie inicjatyw ustawodawczych. Ostrzeżenia lub zalecenia mogą mieć charakter ogólny lub szczegółowy. Ponadto mogą być kierowane do całej Unii, do jednego państwa członkowskiego lub większej ich liczby, do jednego Europejskiego Urzędu Nadzoru lub większej ich liczby, jak również do jednego krajowego organu nadzoru lub większej ich liczby. W przypadku gdy ostrzeżenie lub zalecenie jest kierowane do co najmniej jednego krajowego organu nadzoru, informuje się o tym również zainteresowane państwo członkowskie lub państwa członkowskie. Zalecenia muszą zawierać konkretny termin na podjęcie właściwych działań. Mogą one być również kierowane do Komisji i mogą dotyczyć stosownych przepisów unijnych. Ostrzeżenia lub zalecenia przekazywane adresatom są jednocześnie, zgodnie z zasadami ścisłej poufności, przekazywane Radzie oraz Komisji, a jeżeli są skierowane do co najmniej jednego krajowego organu nadzoru, przekazuje się je również Europejskim Urzędom Nadzoru. W celu zwiększenia świadomości ryzyk zagrażających unijnej gospodarce i priorytetowego traktowania

23 Rozporządzenie Parlamentu Europejskiego i Rady Unii Europejskiej nr 1092/2010 z dnia 24 listopada 2010 r. w sprawie unijnego nadzoru makroostrożnościowego nad systemem finansowym i ustanowienia Europejskiej Rady ds. Ryzyka Systemowego, art. 3 ust 1.

${ }_{24}$ Por. ibidem, art. 4 ust. 1. 
takich ryzyk, ERRS, w ścisłej współpracy z innymi podmiotami wchodzącymi w skład Europejskiego Systemu Nadzoru Finansowego, opracowuje system oznaczeń oparty na kolorach odpowiadających sytuacjom o różnych poziomach ryzyka ${ }^{25}$.

W przypadku gdy zalecenie kierowane jest do Komisji, co najmniej jednego państwa członkowskiego, co najmniej jednego Europejskiego Urzędu Nadzoru lub co najmniej jednego krajowego organu nadzoru, adresaci są zobowiązani poinformować ERRS i Radę o działaniach podjętych w odpowiedzi na zalecenia i przedstawić odpowiednie uzasadnienie w przypadku braku działania. W stosownych przypadkach Europejskie Urzędy Nadzoru są - z zastrzeżeniem zasad ścisłej poufności - bezzwłocznie informowane przez ERRS o otrzymanych odpowiedziach. W przypadku gdy ERRS ustali, że jej zalecenie nie zostało wykonane, a adresaci nie wyjaśnili odpowiednio swojego braku działania, informuje o tym - także z zastrzeżeniem zasad ścisłej poufności - adresatów, Radę a w stosownych przypadkach także właściwe Europejskie Urzędy Nadzoru ${ }^{26}$.

Jednym z głównych elementów reformy nadzoru finansowego w UE było także powołanie trzech Europejskich Urzędów Nadzoru (European Supervisory Authorities - ESA) w miejsce wcześniej funkcjonujących komitetów nadzorców europejskich (CEBS, CEIOPS, CESR), zwanych komitetami trzeciego poziomu procedury Lamfalussy’ego. Siedziby nowo powstałych Europejskich Urzędów Nadzoru są umiejscowione $\mathrm{w}$ dotychczasowych siedzibach odpowiednich komitetów, czyli w Londynie ${ }^{27}$, Frankfurcie ${ }^{28}$ oraz Paryżu ${ }^{29}$. Mają one jednak znacznie szerszy zakres zadań, a także uprawnień i kompetencji. Do zadań Europejskich Urzędów Nadzoru należy m.in.:

- przyczynianie się do ustanowienia wspólnych standardów oraz praktyk regulacyjnych i nadzorczych o wysokiej jakości, w szczególności poprzez przedstawianie opinii instytucjom UE oraz poprzez opracowywanie wytycznych, zaleceń i projektów regulacyjnych i wykonawczych standardów technicznych;

- przyczynianie się do spójnego stosowania prawnie wiążących aktów unijnych, w szczególności poprzez budowanie wspólnej kultury nadzoru, zapewnianie

25 Por. ibidem, art. 16

26 Por. ibidem, art. 17.

27 Rozporządzenie Parlamentu Europejskiego i Rady UE nr 1093/2010 z dnia 24 listopada 2010 r. w sprawie ustanowienia Europejskiego Urzędu Nadzoru (Europejskiego Urzędu Nadzoru Bankowego), zmiany decyzji nr 716/2009/WE oraz uchylenia decyzji Komisji 2009/78/WE, art. 7.

28 Rozporządzenie Parlamentu Europejskiego i Rady UE nr 1094/2010 z dnia 24 listopada 2010 r. w sprawie ustanowienia Europejskiego Urzędu Nadzoru (Europejskiego Urzędu Nadzoru Ubezpieczeń i Pracowniczych Programów Emerytalnych), zmiany decyzji nr 716/2009/WE oraz uchylenia decyzji Komisji 2009/79/WE, art. 7.

29 Rozporządzenie Parlamentu Europejskiego i Rady UE nr 1095/2010 z dnia 24 listopada 2010 r. w sprawie ustanowienia Europejskiego Urzędu Nadzoru (Europejskiego Urzędu Nadzoru Giełd i Papierów Wartościowych), zmiany decyzji nr 716/2009/WE oraz uchylenia decyzji Komisji 2009/77/WE, art. 7. 
spójnego, efektywnego i skutecznego stosowania odpowiednich aktów prawa UE, zapobieganie arbitrażowi regulacyjnemu, mediację i rozstrzyganie sporów między właściwymi organami, zapewnianie skutecznego i spójnego nadzoru nad instytucjami finansowymi, zapewnianie spójności działań kolegiów organów nadzoru oraz podejmowanie działań, m.in. w sytuacjach nadzwyczajnych; - wspieranie i ułatwianie delegowania zadań i kompetencji pomiędzy właściwymi organami;

- ścisła współpraca z Europejską Radą ds. Ryzyka Systemowego, w szczególności poprzez dostarczanie wszelkich informacji koniecznych do realizacji jej zadań oraz poprzez zapewnianie podejmowania odpowiednich działań następczych w związku z jej ostrzeżeniami i zaleceniami;

- organizowanie i przeprowadzanie analizy wzajemnych ocen właściwych organów, w tym wydawanie wytycznych i zaleceń oraz określanie najlepszych praktyk w celu zwiększenia spójności wyników w zakresie nadzoru;

- monitorowanie i ocenianie zmian na rynkach podlegających kompetencjom urzędów;

- przeprowadzanie analiz ekonomicznych rynków w celu informowania o wykonywaniu zadań przez urząd;

- wzmacnianie ochrony deponentów i inwestorów (w przypadku EBA), ubezpieczonych, członków pracowniczych programów emerytalnych i uposażonych (w przypadku EIOPA), inwestorów (w przypadku ESMA);

- przyczynianie się do konsekwentnego i spójnego funkcjonowania kolegiów organów nadzoru, monitorowania, oceniania i mierzenia ryzyka systemowego, opracowywania i koordynowania planów naprawczych, zapewniania wysokiego poziomu ochrony wskazanym powyżej osobom w całej Unii oraz w przypadku EBA i ESMA - opracowywania metod prowadzenia postępowania naprawczego wobec upadających instytucji finansowych/uczestników rynków finansowych, a także do oceniania zapotrzebowania na odpowiednie instrumenty finansujące ${ }^{30}$. Europejskie Urzędy Nadzoru (ESA) nie sprawują bezpośredniego nadzoru nad instytucjami finansowymi, ale mają możliwość wydawania w określonych sytuacjach decyzji wiążących krajowe organy nadzoru. Ponadto do zadań ESA nadal ma należeć opracowywanie wytycznych, doradzanie Komisji Europejskiej, podejmowanie działań na rzecz konwergencji praktyk nadzorczych czy przeprowadzanie wzajemnych ocen. Urzędom zostały także przyznane kompetencje związane $\mathrm{z}$ ochroną konsumentów, takie jak: gromadzenie i analizowanie informacji na temat tendencji w zachowaniach konsumentów oraz składanie odnośnych sprawozdań; analizowanie

30 Por. Rozporządzenie Parlamentu Europejskiego i Rady UE nr 1093/2010, op.cit., art. 8. 
i koordynowanie znajomości zagadnień finansowych i inicjatyw edukacyjnych realizowanych przez właściwe organy; możliwość czasowego zakazu prowadzenia lub ograniczenia prowadzenia pewnych typów działalności finansowej, które zagrażają prawidłowemu funkcjonowaniu i integralności rynków finansowych lub stabilności całego systemu finansowego w Unii lub jego części, przypadkach określonych w aktach ustawodawczych UE.

Ponadto odpowiednie rozporządzenia przewidują obowiązki ESA związane z identyfikacją i mierzeniem ryzyk systemowych, opracowywaniem i koordynowaniem planów naprawczych dla instytucji finansowych, wzmacnianiem systemów gwarancyjnych właściwych dla danego sektora, uczestniczeniem w opracowywaniu metod prowadzenia postępowania naprawczego wobec upadających instytucji finansowych, w szczególności tych, które mogą stwarzać ryzyko systemowe.

Zasadniczym elementem Europejskiego Systemu Nadzoru Finansowego jest także Wspólny Komitet Europejskich Urzędów Nadzoru. Stanowi on forum, w ramach którego urzędy nadzoru prowadzą regularną i ścisłą współpracę. Zapewnia on międzysektorową spójność z Europejskim Urzędem Nadzoru Bankowego, Europejskim Urzędem Nadzoru Ubezpieczeń i Pracowniczych Programów Emerytalnych i Europejskim Urzędem Nadzoru Giełd i Papierów Wartościowych, zwłaszcza w odniesieniu do:

- konglomeratów finansowych;

- księgowości i audytu;

- analiz mikroostrożnościowych pod kątem rozwoju sytuacji, zagrożeń i słabości związanych ze stabilnością finansową;

- detalicznych produktów inwestycyjnych;

- środków przeciwdziałania praniu brudnych pieniędzy;

- wymiany informacji z ERRS oraz rozwoju stosunków między ERRS a Europejskimi Urzędami Nadzoru.

W skład Wspólnego Komitetu wchodzą przewodniczący Europejskich Urzędów Nadzoru, a także, w stosownych przypadkach, przewodniczący podkomitetów które mogą być w jego ramach powoływane. Natomiast dyrektor wykonawczy, przedstawiciel Komisji i Europejskiej Rady ds. Ryzyka Systemowego są zapraszani do uczestniczenia w charakterze obserwatorów w posiedzeniach Wspólnego Komitetu oraz ewentualnych podkomitetów. Przewodniczący Wspólnego Komitetu wybierany jest co roku na zasadzie rotacji spośród przewodniczących Europejskich Urzędów Nadzoru. Jest on jednocześnie wiceprzewodniczącym ERRS. Wspólny Komitet uchwala i publikuje swój regulamin wewnętrzny, w którym mogą zostać określeni inni uczestnicy jego posiedzeń. Te z kolei powinny odbywać się co najmniej raz 
na dwa miesiące ${ }^{31}$. W ramach swoich zadań urząd wypracowuje w stosownych przypadkach wspólne stanowiska z Europejskimi Urzędami Nadzoru.

\subsection{Stały mechanizm stabilizacyjny w strefie euro}

Zła sytuacja w sferze finansów publicznych owocuje także zwiększoną aktywnością państw w wielu regionach, w tym także w strefie euro. Tworząc Unie Gospodarczą i Walutową, nie przewidziano wystarczających mechanizmów pomocowych w sytuacji poważnych problemów finansowych i gospodarczych państw członkowskich. Szczególnie uwidoczniło się to po załamaniu gospodarczym 2007+. Jako pierwsza poważne trudności zaczęła przeżywać Grecja, a w jej ślady poszły gospodarki Irlandii i Portugalii. Obecnie sytuacja zagrożenia dotyczy Hiszpanii i Włoch. W odpowiedzi na zaistniałą sytuację państwa członkowskie podjęły w pierwszej kolejności działania tymczasowe, a następnie przystąpiły do tworzenia stałych mechanizmów stabilizacyjnych.

\subsubsection{Rozwiązania przejściowe}

Działania tymczasowe, które oficjalnie mają obowiązywać do momentu wprowadzenia bardziej trwałych rozwiązań, sprowadzają się do ustanowienia Europejskiego Mechanizmu Stabilizacji Finansowej i Europejskiego Instrumentu Stabilności Finansowej, funkcjonującego poprzez Europejski Fundusz Stabilności Finansowej. Ich wprowadzenie w życie wzbudzało szereg wątpliwości także natury prawnej. Związane było to $\mathrm{z}$ uruchamianiem pomocy i udzielaniem wsparcia m.in. instytucjom publicznym i przestrzeganiem reguł rynkowych, a także zasad uczciwej konkurencji. Europejski mechanizm stabilizacji finansowej powołano na mocy rozporządzeniem Rady (UE) nr 407/2010 z dnia 11 maja 2010 r. ${ }^{32}$. Uzyskał on pełną gwarancję budżetu UE. W art. 1 ustalono, że dla zachowania stabilności finansowej Unii Europejskiej pomoc finansowa Unii może zostać przyznana państwu członkowskiemu, które ma poważne trudności gospodarcze lub finansowe lub też jest nimi istotnie zagrożone, z racji nadzwyczajnych okoliczności pozostających poza jego kontrolą. Utrzymano natomiast możliwość zastosowania obowiązującego instrumentu średnioterminowej

31 Rozporządzenie Parlamentu Europejskiego i Rady UE nr 1093/2010 z dnia 24 listopada 2010 r., op.cit., art. 54-55, Rozporządzenie Parlamentu Europejskiego i Rady UE nr 1094/2010 z dnia 24 listopada 2010 r., op.cit., art. 54-55, a także Rozporządzenie Parlamentu Europejskiego i Rady UE nr 1095/2010 z dnia 24 listopada 2010 r., op.cit., art. 54-55.

32 Odwołano się w nim do art. 122 ust. 2 traktatu o funkcjonowaniu Unii Europejskiej, który przewiduje możliwość przyznawania pomocy finansowej państwom członkowskim, które znalazły się w trudnej sytuacji z racji nadzwyczajnych okoliczności pozostających poza ich kontrolą. 
pomocy finansowej dla bilansów płatniczych państw członkowskich nienależących do strefy euro, ustanowionego rozporządzeniem (WE) nr 332/2002.

Pomoc finansowa Unii w ramach Europejskiego Mechanizmu Stabilizacji Finansowej może przyjmować formę zarówno pożyczki, jak i linii kredytowej udzielonej danemu państwu członkowskiemu. W tym celu Komisja została upoważniona w imieniu Unii Europejskiej do zaciągania pożyczek na rynkach kapitałowych lub od instytucji finansowych. Uruchomienie mechanizmu zostało obwarowane rygorystycznymi warunkami, szczególnie ze względu na zaangażowanie Międzynarodowego Funduszu Walutowego.

Kolejne narzędzie - Europejski Instrument Stabilności Finansowej (Europejski Fundusz Stabilności Finansowej) - został utworzony w czerwcu 2010 r. przez państwa członkowskie strefy euro jako spółka będąca ich własnością, z siedzibą w Luksemburgu, zgodnie z decyzjami podjętymi 9 maja 2010 r. w ramach Rady ECOFIN. Europejski Fundusz Stabilności Finansowej może emitować obligacje o łącznej wartości do 440 mld euro, gwarantowane przez państwa członkowskie strefy euro $^{33}$, przy czym środki pozyskiwane $z$ emisji tych obligacji są następnie udostępniane $\mathrm{w}$ formie pożyczek państwom członkowskim strefy euro znajdującym się w trudnej sytuacji, na warunkach wynegocjowanych z Komisją działającą w porozumieniu z Europejskim Bankiem Centralnym i Międzynarodowym Funduszem Walutowym oraz zatwierdzonych przez Eurogrupę. Udzielanie pożyczek przez Europejski Fundusz Stabilności Finansowej w odróżnieniu od Europejskiego Mechanizmu Stabilizacji Finansowej nie jest objęte gwarancją budżetu UE.

\subsubsection{Próby stworzenia stałego mechanizmu pomocowego}

Przedstawione powyżej narzędzia powinny być traktowane jako tymczasowe. Nie można mieć jednak wątpliwości, że problemy z nadmiernym zadłużeniem czy też nierównowagą na rachunku bieżącym nie są przejściowe czy krótkotrwałe. Co więcej, panuje powszechne przekonanie, że tylko globalne współdziałanie państw może przyczynić się do stabilizacji sytuacji w wymiarze średnio- i długookresowym. $\mathrm{W}$ tym duchu wypowiadają się i oczekują konkretnych rozwiązań przedstawiciele państw z obu stron Atlantyku. Niezbędne jest także stworzenie uniwersalnych i transparentnych mechanizmów udzielania pomocy w sytuacjach kryzysowych. Można

${ }^{33}$ Po zmianach zakończonych ratyfikacją w październiku 2011 r. poziom tez zwiększy się do 780 mld euro, a poziom pożyczek zwiększy się z $250 \mathrm{mld}$ do $440 \mathrm{mld}$ euro. Planowane jest jednak dalsze powiększanie tej kwoty obecnie docelowo do 1 bln euro. Jednak pewnym cieniem na możliwość zgromadzenia odpowiednich środków z emisji obligacji przez fundusz kładą się obniżki ratingów państw gwarantujących tę emisję, która może negatywnie odbić się na ratingu samego EFSF, a tym samym spadku zainteresowania emitowanymi przez niego papierami dłużnymi potencjalnych inwestorów. 
przyjąć, że w tym nurcie mieści się inicjatywa podjęta przez państwa Unii Europejskiej, a przede wszystkim strefy euro w postaci Europejskiego Mechanizmu Stabilności Finansowej.

Rozmowy w sprawie utworzenia stałych mechanizmów uruchamianych w warunkach kryzysowych prowadzone były od dawna. Jednak dopiero na posiedzeniu Rady Europejskiej w dniach 28-29 października 2010 r. szefowie państw i rządów zgodzili się, że państwa członkowskie powinny ustanowić stały mechanizm kryzysowy służący ochronie stabilności finansowej strefy euro jako całości. Ministrowie Eurogrupy uzgodnili także, że będzie on opierał się na Europejskim Instrumencie Stabilności Finansowej (Europejskim Funduszu Stabilności Finansowej) i będzie mógł zapewniać pakiety pomocy finansowej państwom członkowskim strefy euro, z zastrzeżeniem spełnienia rygorystycznych warunków zgodnie z zasadami obecnego Europejskiego Instrumentu Stabilności Finansowej. Uzgodniono także, że nowy mechanizm będzie stanowił uzupełnienie nowych ram wzmocnionego zarządzania gospodarczego ${ }^{34}$ w celu uzyskania skutecznego i ścisłego nadzoru ekonomicznego, który powinien skupić się na zapobieganiu i znacząco zmniejszy prawdopodobieństwo wystąpienia kryzysu w przyszłości ${ }^{35}$.

Jednocześnie 16 grudnia 2010 r. Rada Europejska, zgodnie z art. 48 ust. 6, akapit 2 TUE, uruchomiała procedurę konsultacji z Parlamentem Europejskim, Komisją Europejską i Europejskim Bankiem Centralnym. Ten ostatni wydał pozytywną opinię w dniu 17 marca 2011 r., a całą procedurę konsultacji zakończono po wydaniu opinii Parlamentu Europejskiego w dniu 23 marca 2011 r. Dzięki takiemu przebiegowi wydarzeń podczas szczytu Rady Europejskiej w dniach 24-25 marca 2011 r. zaprezentowano ogólne zasady funkcjonowania nowego stałego mechanizmu stabilności finansowej nazwanego Europejskim Mechanizmem Stabilności (EMS). Ma on być uruchamiany za wspólnym porozumieniem ${ }^{36}$, w przypadku gdyby było to niezbędne dla ochrony stabilności finansowej strefy euro jako całości. Europejski Mechanizm Stabilności ma przejąć rolę Europejskiego Instrumentu Stabilności Finansowej i Europejskiego Mechanizmu Stabilizacji Finansowej przy zapewnianiu zewnętrznej pomocy finansowej państwom członkowskim strefy euro po czerwcu 2013 roku.

Dostęp do pomocy finansowej z Europejskiego Mechanizmu Stabilności ma być zapewniany w oparciu o rygorystyczne warunki polityczne na mocy makroekonomicznego programu dostosowawczego oraz rygorystycznej analizy zdolności obsługi

34 Tzw. sześciopak, o którym szerzej w dalszej części opracowania.

35 Por. Rada Europejska, 16-17 grudnia 2010 r., Konkluzje. EUCO 30/1/10 REV 1, s. 8-9.

36 Decyzja podejmowana za wspólnym porozumieniem jest decyzją podejmowaną jednomyślnie przez państwa członkowskie biorące udział w tym głosowaniu, tzn. wstrzymanie się od głosu nie uniemożliwia przyjęcia decyzji. 
zadłużenia publicznego. Analizy te ma przeprowadzać Komisja Europejska wraz z Międzynarodowym Funduszem Walutowym i we współpracy z Europejskim Bankiem Centralnym. Państwo członkowskie będące beneficjentem ma zostać zobowiązane do wprowadzenia odpowiedniej formy udziału sektora prywatnego, z uwzględnieniem konkretnych okoliczności oraz w sposób w pełni zgodny z praktykami MFW.

Ustalono także, że Europejski Mechanizm Stabilności będzie miał efektywną zdolność udzielania pożyczek w wysokości 500 mld euro ${ }^{37}$. Adekwatność zdolności udzielania pożyczek ma podlegać regularnym przeglądom przynajmniej co pięć lat. Ponadto Europejski Mechanizm Stabilności ma dążyć do uzupełnienia swojej zdolności udzielania pożyczek przez udział MFW w operacjach pomocy finansowej. Podjęto decyzję, że państwa członkowskie spoza strefy euro także mogą uczestniczyć w EMS na zasadzie ad hoc ${ }^{38}$.

Na posiedzeniu Rady Europejskiej w marcu 2011 r., oprócz ogólnych kwestii związanych z Europejskim Mechanizmem Stabilności, ustalono także wiele rozwiązań szczegółowych. Rozstrzygnięto np., że EMS zostanie ustanowiony w drodze porozumienia między państwami członkowskimi strefy euro jako organizacja międzyrządowa na mocy międzynarodowego prawa publicznego, a swą siedzibę będzie miał w Luksemburgu, czyli tam, gdzie siedzibę ma EFSF ${ }^{39}$. Rola Europejskiego Mechanizmu Stabilności ma polegać na uruchamianiu finansowania i udzielaniu pomocy finansowej - w oparciu o rygorystyczne warunki - na rzecz państw członkowskich strefy euro, które mają poważne problemy z finansowaniem lub są zagrożone takimi problemami, aby chronić stabilność finansową strefy euro jako całości. Państwa członkowskie strefy euro zostały zobowiązane w ramach przyjętych rozwiązań do przekazywania do Europejskiego Mechanizmu Stabilności kwoty sankcji finansowych nałożonych na nie na mocy paktu stabilności i wzrostu oraz procedur dotyczących zakłóceń równowagi makroekonomicznej. Takie sankcje będą stanowiły część kapitału wpłaconego.

Europejski Mechanizm Stabilności ma ściśle współpracować z MFW w udzielaniu pomocy finansowej ${ }^{40}$. W każdej sytuacji powinno dążyć się do aktywnego udziału MFW zarówno na poziomie technicznym, jak i finansowym. Analiza zdolności obsługi zadłużenia ma być prowadzona wspólnie przez Komisję oraz MFW,

37 Podczas przechodzenia z Europejskiego Instrumentu Stabilności Finansowej do Europejskiego Mechanizmu Stabilności łączna zdolność udzielania pożyczek nie powinna przekroczyć powyższej kwoty. Jednak w świetle ostatnich zmian w ramach EFSF wydaje się to mało prawdopodobne.

38 Por. Rada Europejska, 24-25 marca 2011 r., Konkluzje. EUCO 10/1/11, s. 21.

39 Statut Europejskiego Mechanizmu Stabilności ma zostać umieszczony w załączniku do wspomnianego porozumienia.

40 Zakłada się jednak, że jakikolwiek udział MFW musi być zgodny z jego mandatem wynikającym z aktu ustanawiającego ten fundusz (articles of agreement) i z mającą zastosowanie decyzją oraz z polityką MFW. 
we współpracy z EBC. Warunki polityczne związane ze wspólną pomocą Europejskiego Mechanizmu Stabilności i MFW mają być negocjowane wspólnie przez Komisję i MFW we współpracy z EBC.

W ramach ESM przewiduje się także klauzule wspólnego działania. Od lipca 2013 r. mają one być wpisane do wszystkich nowych rządowych papierów wartościowych strefy euro o zapadalności przekraczającej jeden rok. W kontekście udziału sektora prywatnego klauzule takie będą miały ułatwiać danemu państwu osiągnięcie porozumienia z wierzycielami pochodzącymi z sektora prywatnego. Umieszczenie klauzul w obligacji nie będzie oznaczać mniejszej pewności spłaty ani większego ryzyka restrukturyzacji długu. Włączenie tych klauzul nie wpłynie też na status wierzycielski długu państwowego ${ }^{41}$. Mają one zostać wprowadzone tak, by zapewnić równe traktowanie wszystkim państwom członkowskim strefy euro. Oznacza to, że dla wszystkich tych państw klauzule będą miały identyczne, standardowe brzmienie, zharmonizowane w ramach warunków obowiązujących w odniesieniu do papierów wartościowych emitowanych przez państwa członkowskie

Wśród wspomnianych klauzul ma być klauzula agregacji wierzytelności, pozwalająca większości posiadaczy obligacji, które pochodzą z różnych emisji i podlegają takiej klauzuli oraz prawu tej samej jurysdykcji, posłużyć się klauzulą większościowego działania, jeżeli w ramach jednej emisji obligacji nie udałoby się zgromadzić odpowiedniej większości wierzycieli potrzebnej do restrukturyzacji długu. Ustalone mają być także odpowiednie zasady reprezentacji. Sprawy ważniejsze, tzn. zastrzeżone (np. najważniejsze warunki płatności, konwersja lub wymiana obligacji), będą rozstrzygane większością większą niż sprawy niezastrzeżone. Zastosowanie mają mieć odpowiednie wymogi co do kworum. Zmiany uchwalone przez wymaganą większość będą wiążące dla wszystkich właścicieli obligacji. Aby głosowanie przebiegało właściwie, zastosowanie ma mieć odpowiednia klauzula pozbawiania głosu. Rozważone mają zostać odpowiednie klauzule przeciwko zakłócającym działaniom prawnym.

Klauzule wspólnego działania mają być wprowadzane w sposób standardowy, tak by ich skutek prawny we wszystkich jurysdykcjach strefy euro był identyczny i żadne państwa członkowskie do niej należące nie były dyskryminowane. Ponadto państwa członkowskie strefy euro mają przyjmować wszelkie środki konieczne, aby nadać skuteczność klauzulom wspólnego działania. Pod wcześniej ustalonymi warunkami państwom członkowskim strefy euro będzie wolno nadal, po czerwcu 2013 roku, emitować papiery dłużne bez tych klauzul, tak by państwa te mogły zachować konieczną

41 Główne elementy tych klauzul będą odpowiadać klauzulom powszechnie stosowanym na rynkach brytyjskich i amerykańskich od czasu sprawozdania grupy G10 na temat takich klauzul. 
płynność starych obligacji i by miały wystarczająco dużo czasu na uporządkowane stworzenie nowych obligacji o wszelkich referencyjnych terminach zapadalności. Szczegółowe rozwiązania prawne umożliwiające umieszczanie klauzul wspólnego działania w rządowych papierach wartościowych strefy euro mają zostać ustalone na podstawie prac, które po odpowiednich konsultacjach z uczestnikami rynków i innymi zainteresowanymi stronami ma przeprowadzić Podkomitet ds. unijnych rynków długu państwowego, działający w ramach Komitetu ekonomiczno-finansowego ${ }^{42}$.

Państwa członkowskie spoza strefy euro także mogą uczestniczyć doraźnie wraz $\mathrm{z}$ europejskim mechanizmem stabilności w akcjach pomocy finansowej dla państw członkowskich strefy euro. W takiej sytuacji mają one być reprezentowane na odnośnych posiedzeniach organów zarządzających mechanizmu, które będą decydować o przyznaniu i monitorowaniu pomocy. Ponadto mają one mieć szybki dostęp do wszelkich odnośnych informacji, jak również muszą być z nimi prowadzone odpowiednie konsultacje ${ }^{43}$.

\section{Skutki podejmowanych działań i perspektywa rozwoju sytuacji}

Podejmowane działania miały doprowadzić do ustabilizowania sytuacji w sektorze finansowym, przywrócenia zaufania do tych instytucji, jak również ożywienia w realnej sferze gospodarki. Pierwsze oznaki ożywienia pojawiły się w 2009 r. W kolejnym roku wydawało się, że sytuacja się ustabilizowała, a gospodarka światowa powoli, ale jednak wychodzi z kryzysu. Niestety, kolejne kwartały 2011 roku wskazały, że obserwowane wcześniej oznaki ożywienia powoli zanikają, a perspektywa na kolejne miesiące i lata jest bardzo niepewna. Tak więc oczekiwania, szczególnie w grupie państw rozwiniętych, nie są optymistyczne. Nie może więc budzić zdziwienia fakt powrotu dyskusji na temat pozycji i aktywności państwa. Tym bardziej że w wyniku zastosowanych w przeszłości pakietów pomocowych i stymulacyjnych o fiskalnym charakterze - $\mathrm{w}$ wielu przypadkach $\mathrm{w}$ państwach o wysokiej nierównowadze finansów publicznych - mamy do czynienia z narastającym zadłużeniem, głównie w gronie państw rozwiniętych. Ponadto aktywność banków centralnych w przywracaniu zaufania do instytucji finansowych oraz stabilności międzynarodowego

\footnotetext{
42 Por. Konkluzje Rady Europejskiej z 24-25 marca 2011 r., op.cit., s. 31-32.

43 Por. ibidem, s. 33. Doniesienia z początku 2012 r. wskazują jednak, że udział państw członkowskich UE spoza strefy euro we właściwych organach zarząazających mechanizmem może być utrudniony lub wręcz niemożliwy.
} 
systemu finansowego doprowadziły do sytuacji, w której zestaw instrumentów dostępnych władzom monetarnym na szczeblu państw w zwalczaniu zjawisk kryzysowych jest bardzo ograniczony. Tym samym próby wskazywania, że w obecnych uwarunkowaniach ciężar stymulowania gospodarek powinien być przeniesiony z polityki fiskalnej na politykę pieniężną nie wydaje się wiarygodny.

Można domniemywać, że opinię tę potwierdzają ostatnie decyzje Systemu Rezerwy Federalnej USA w sprawie jego zaangażowania w działania na rzecz podniesienia aktywności gospodarczej i ograniczanie stopy bezrobocia. Standardowe instrumenty są albo wyczerpane, albo nieskuteczne, dlatego już w pierwszej fazie FED korzystał z tzw. niestandardowych instrumentów, w szczególności z tzw. poluzowania ilościowego. W praktyce oznaczało to dostarczanie pieniądza do gospodarki. W związku z tym przypuszczano, że w sytuacji pogarszających się perspektyw zarówno dla gospodarki amerykańskiej, jak i europejskiej (głównie w strefie euro) FED zdecyduje się na trzecie poluzowanie i dodruk pieniędzy. Tymczasem po miesięcznym przeciąganiu podjęcia decyzji we wrześniu 2011 r. zdecydowano się jedynie na akcję twist. Polega ona na tym, iż do czerwca 2012 r. FED kupi za $400 \mathrm{mld}$ dol. papiery dłużne o terminie zapadalności od 6 do 30 lat i jednocześnie sprzeda papiery dłużne o tej samej wartości o krótkim terminie zapadalności, czyli do trzech lat. Ma to doprowadzić do zwiększenia masy pieniądza w systemie bankowym. Nie ma jednak gwarancji, że przyczyni się do zwiększenia akcji kredytowej.

O ograniczoności instrumentów, jak również realnych pomysłów na rozwiązanie nasilających się problemów świadczy zachowanie instytucji na starym kontynencie. Przykładowo Europejski Bank Centralny zdecydował się na uruchomienie od połowy listopada $2011 \mathrm{r}$. skupu obligacji w celu zasilenia sektora bankowego w płynność o wartości 40 mld euro. Bank Anglii natomiast przez 4 miesiące skupował obligacje o wartości 75 mld funtów, przez co cały pakiet zasilania systemu bankowego i gospodarki w dodatkowy pieniądz wyniesie już 270 mld funtów. Ponownie zdecydowano się na pomoc bankom także w skrajne formule, np. gdy ujawniły się problemy banków skażonych papierami dłużnymi wyemitowanymi przez Grecję. W trudnej sytuacji znalazł się belgijsko-francuski bank Dexia. W jego przypadku stosunkowo szybko zdecydowano się na radykalne kroki. Polegają one na restrukturyzacji i nacjonalizacji belgijskiej części banku za kwotę 4 mld euro. Bankowi udzielono także gwarancji na 90 mld przez rządy Francji, Belgii i Luksemburga.

Wydaje się, że także optymizm na gruncie europejskim w związku z przyjęciem przez Parlament Europejski i Radę sześciu rozporządzeń dotyczących: wzmocnienia nadzoru nad pozycjami budżetowymi oraz nadzoru i koordynacji polityk 
gospodarczych ${ }^{44}$, nadzoru budżetowego w strefie euro ${ }^{45}$, środków egzekwowania korekty nadmiernych zaburzeń równowagi makroekonomicznej w strefie euro ${ }^{46}$, zapobiegania zaburzeniom równowagi makroekonomicznej i ich korygowania ${ }^{47}$, przyspieszenia i wyjaśnienia procedury nadmiernego deficytu ${ }^{48} \mathrm{i}$ wymogów dotyczących ram budżetowych w państwach członkowskich ${ }^{49}$ jest nieco przesadzony. Samą inicjatywę należy oceniać pozytywnie - próbowano w niej wprowadzić automatyczne nakładanie sankcji na państwa członkowskie niedotrzymujące kryteriów zadłużenia określonych w pakcie stabilności i wzrostu ${ }^{50}$. Kompromis, ostatecznie zatwierdzony 28 września 2011 r. przez Parlament Europejski, a następnie 3 października 2011 r. przez Radę Europejską, przewiduje, że Komisja Europejska będzie mogła udzielić ostrzeżenia państwu członkowskiemu. Ostrzeżenie to wejdzie w życie w ciągu 10 dni od ogłoszenia, chyba że państwa członkowskie zablokują je większością głosów. W takiej sytuacji Rada będzie musiała publicznie, na forum Parlamentu Europejskiego przedstawić uzasadnienie tej decyzji. Ponadto przy analizowaniu przyczyn nierównowagi makroekonomicznej Komisja Europejska będzie dokonywała oceny nie tylko państw członkowskich wykazujących znaczny deficyt na rachunku obrotów bieżących, ale również tych, które wykazują znaczne nadwyżki. To sprawi, że KE będzie musiała brać pod uwagę możliwość, że źródłem nierównowagi mogą być także państwa $z$ nadwyżką, takie jak Niemcy lub Holandia, i one również będą mogły zostać wezwane do dokonania stosownych korekt. Inne ustalenia dotyczą m.in.: zwiększenia uprawnień Komisji Europejskiej, która będzie otrzymywać więcej

${ }_{44}$ Rezolucja legislacyjna Parlamentu Europejskiego z dnia 28 września 2011 r. w sprawie wniosku dotyczącego rozporządzenia Parlamentu Europejskiego i Rady zmieniającego rozporządzenie (WE) nr 1466/97 w sprawie wzmocnienia nadzoru pozycji budżetowych oraz nadzoru i koordynacji polityk gospodarczych (COM(2010)0526 - C7-0300/2010 - 2010/0280(COD)).

45 Rezolucja legislacyjna Parlamentu Europejskiego z dnia 28 września 2011 r. w sprawie wniosku dotyczącego rozporządzenia Parlamentu Europejskiego i Rady w sprawie skutecznego egzekwowania nadzoru budżetowego w strefie euro (COM(2010)0524 - C7-0298/2010 - 2010/0278(COD)).

46 Rezolucja legislacyjna Parlamentu Europejskiego z dnia 28 września 2011 r. w sprawie wniosku dotyczącego rozporządzenia Parlamentu Europejskiego i Rady w sprawie środków egzekwowania korekty nadmiernych zaburzeń równowagi makroekonomicznej w strefie euro (COM(2010)0525 - C7-0299/2010 - 2010/0279(COD)).

47 Rezolucja legislacyjna Parlamentu Europejskiego z dnia 28 września 2011 r. w sprawie wniosku dotyczącego rozporządzenia Parlamentu Europejskiego i Rady w sprawie zapobiegania zaburzeniom równowagi makroekonomicznej i ich korygowania (COM(2010)0527 - C7-0301/2010 - 2010/0281(COD)).

48 Rezolucja legislacyjna Parlamentu Europejskiego z dnia 28 września 2011 r. w sprawie wniosku dotyczącego rozporządzenia Rady zmieniającego rozporządzenie Rady (WE) nr 1467/97 w sprawie przyspieszenia i wyjaśnienia procedury nadmiernego deficytu (COM(2010)0522 - C7-0396/2010 - 2010/0276(CNS)).

49 Rezolucja legislacyjna Parlamentu Europejskiego z dnia 28 września 2011 r. w sprawie wniosku dotyczącego dyrektywy Rady w sprawie wymogów dotyczących ram budżetowych w państwach członkowskich (COM(2010)0523 - C7-0397/2010 - 2010/0277(NLE)).

50 Automatyzm nie zyskał jednak pełnego poparcia. Przykładowo część państw, w tym Francja, nalegały, aby ostrzeżenia Komisji Europejskiej były każdorazowo akceptowane przez Radę. 
informacji, a także wysyłać misje nadzorujące do państw członkowskich; możliwości zastosowania sankcji w wysokości $0,2 \%$ PKB za fałszowanie statystyk dotyczących deficytu i zadłużenia; wymogu złożenia depozytu oprocentowanego $(0,1 \% \mathrm{PKB})$, w przypadku gdy państwo członkowskie nie podejmie działań naprawczych zmierzających do przywrócenia równowagi makroekonomicznej. Jednak należy mieć na uwadze, że tworząc UGiW określano także rygorystyczne kryteria członkostwa, obowiązki w sferze dyscypliny finansów publicznych oraz kary za jej nieprzestrzeganie $^{51}$. Jaką więc mamy gwarancję, że rozwiązania przyjęte tym razem będą przestrzegane i egzekwowane, a poszczególne państwa będą szczerze zainteresowane dyscypliną finansów publicznych i pogłębioną koordynacją polityki gospodarczej. Obawy te wydaje się potwierdzać inicjatywa państw członkowskich Unii Europejskiej nazwana paktem fiskalnym. Ustalenia przyjęte na szczycie Rady Europejskiej w grudniu 2011 r. zakładają, że dochody i wydatki budżetu administracji centralnej powinny być zrównoważone, deficyt w budżecie może wystąpić tylko w sytuacjach nadzwyczajnych - w okresie pogorszenia koniunktury - jednak nawet wówczas nie powinny przekroczyć 3\% PKB. Ponadto w średnim okresie przeciętny deficyt budżetowy nie powinien przekraczać $0,5 \% \mathrm{PKB}$, a państwa powinny dążyć do obniżenia długu publicznego do poziomu poniżej 60\% PKB. W pakcie wskazano także, że państwa, planując długoterminowo finanse, powinny brać pod uwagę trendy demograficzne, a przede wszystkim efekt starzenia się społeczeństwa. Wprowadza on możliwość stosowania kar wobec państw, które nie będą stosować się do zaleceń Komisji Europejskiej w sferze finansów publicznych, przy czym zablokowanie nałożenia kary na państwo ma wymagać kwalifikowanej większości głosów ${ }^{52}$. Wątpliwe wydaje się jednak, że obniżenie wymogów co do większości pozwalającej nałożyć kary będzie wystarczającym rozwiązaniem. Pozostałe elementy paktu są bowiem dobrze znane. Krytycznie należy się także odnieść do skupienia się jedynie na wydatkowej stronie budżetów bez działań koordynujących w sferze dochodowej, a przede wszystkim systemów podatkowych.

Reasumując, zestaw instrumentów, które będą musiały być wykorzystywane w zwalczaniu narastających zjawisk kryzysowych, jest dużą niewiadomą. Przy czym niepokojący jest nie tylko brak wiedzy co do potencjalnych narzędzi, lecz obawa, że tak naprawdę władze fiskalne i monetarne najważniejszych państw współczesnej gospodarki światowej nie mają pojęcia, jakie działania podejmować. Można

${ }^{51}$ Przykładem państwa, na które nałożono sankcje za przekroczenie progu deficytu budżetowego, była Portugalia.

52 Wprowadzenie paktu fiskalnego wymaga jednak, jeśli nie modyfikacji traktatu, na co są bardzo małe szanse, to przynajmniej przygotowania umowy międzyrządowej i ratyfikowania jej przez państwa członkowskie. Ponadto zakłada się, że umowę mogą podpisać państwa spoza strefy euro. 
oczekiwać, że nie będzie próby uniwersalizacji ewentualnych narzędzi, chyba że będzie ona polegała na kompleksowej restrukturyzacji długów w skali globalnej. Tak więc poszczególne państwa będą starały się, w dużej mierze metodą prób i błędów, z uwzględnieniem pogarszającej się sytuacji na rynku długów, chronić swoje gospodarki przed katastrofą. $\mathrm{W}$ obecnych działaniach, a w zasadzie $\mathrm{w}$ ich braku widać, że są one nastawione na krótkowzroczny i doraźny efekt. Nie widać w nich próby wyjścia w dalszą perspektywę czasową. Nie podejmuje się dyskusji na temat fundamentów doktrynalnych współczesnej gospodarki światowej. Opisane w niniejszym opracowaniu przedsięwzięcia także wpisują się w ten nurt. Są one bowiem odpowiedzią na zaistniałą sytuację, a nie inicjatywą, która wyprzedziła bieżące zjawiska kryzysowe. Także próba poszukiwania winnych niewielkiej skuteczności programów stymulacyjnych w gospodarce amerykańskiej poza jej granicami potwierdza dominację XX-wiecznej doktryny i nie napawa optymizmem ${ }^{53}$.

\section{Zakończenie}

Kryzys finansowy 2007+ i załamanie w realnej sferze wielu gospodarek istotnych dla współczesnego ładu ekonomicznego doprowadziły do inicjatyw ukierunkowanych na ograniczanie i ewentualne przeciwdziałanie negatywnym zjawiskom. Zasadniczą rolę w działaniach pomocowych odgrywało państwo i jego instytucje. Początkowo poszczególne państwa koncentrowały się na przedsięwzięciach z zakresu polityki fiskalnej i pieniężnej ukierunkowanych na pomoc krajowym podmiotom gospodarczym. Tym samym wyzwania, jakie przyniósł początek XXI wieku, zmieniły oczekiwania co do pozycji i znaczenia współczesnego państwa. Jednak relatywnie szybko okazało się, że pomoc o takim charakterze nie jest wystarczająca. Zaawansowany poziom kooperacji i współzależności międzynarodowej między podmiotami o charakterze mikro- i makroekonomicznym doprowadził do sytuacji, w której pojedyncze państwa nie były w stanie skutecznie przeciwdziałać zjawiskom kryzysowym inicjowanym nie tylko wewnątrz ich gospodarek, ale także importowanym z otoczenia. Tym samym coraz częściej spotykamy się z pomocą o międzynarodowym charakterze dla państw i innych podmiotów, w której - zgodnie z nowymi oczekiwaniami - kluczową rolę ogrywają same państwa wspierane przez organizacje międzynarodowe. W Europie pojawiają się inicjatywy zapraszania do pomocy także

53 Por. wypowiedź prezydenta Baraka Obamy z początku października $2011 \mathrm{r}$. wskazującą, że za pogarszającą sytuację gospodarki amerykańskiej odpowiedzialna jest dumpingowa polityka kursowa Chin. 
instytucji prywatnych - trzecia transza pomocy dla Grecji i próba zaangażowania banków prywatnych. Należy jednak wyraźnie podkreślić, że ta nowa międzynarodowa aktywność państw w zakresie pomocy innym krajom nie ma charakteru altruistycznego ${ }^{54}$. Można domniemywać, że bez tych działań narastająca niepewność na rynkach finansowych, niewypłacalność wielu podmiotów, w tym także państw, niestabilność na rynkach walutowych, zahamowanie tendencji wzrostowych w realnej sferze gospodarek, odbiłyby się znacznie bardziej dotkliwie na gospodarkach państw udzielających pomocy międzynarodowej i wygenerowałyby dużo większe koszty.

Ponadto można zauważyć, że zmiany zachodzą nie tylko w ogólnym znaczeniu państwa we współczesnej gospodarce światowej, lecz także w obrębie samych państw. Po raz pierwszy od dziesięcioleci dochodzi bowiem do sytuacji, w której państwa do niedawana postrzegane jako podmioty mogące potencjalnie destabilizować gospodarkę międzynarodową, jak np. Brazylia czy Meksyk, stają się kredytodawcami dla państw rozwiniętych. Wspierają one potrzeby pożyczkowe sektora publicznego głównie państw europejskich, które przeżywają poważne problemy. W pewnym sensie starają się wspierać działania na rzecz ratowania strefy euro.

Tak więc wydarzenia ostatnich lat nie tylko doprowadziły do zwiększonej aktywności państw $\mathrm{w}$ wewnętrznym wymiarze, $\mathrm{w}$ tym $\mathrm{w}$ wielu przypadkach także do katastrofalnej sytuacji w finansach publicznych, lecz także do rozwoju współpracy międzynarodowej na międzyrządowym poziomie, ze szczególnym udziałem organizacji międzynarodowych również o międzyrządowym charakterze. W przypadku Europy zainicjowały one dyskusję nad zacieśnianiem współpracy gospodarczej w sferze fiskalnej. Przywrócono także do dyskusji kwestię wyposażenia Międzynarodowego Funduszu Walutowego w funkcję kredytodawcy ostatniej instancji. Wskazuje to, że w nowych uwarunkowaniach międzynarodowych banki centralne wielu państw, w tym także rozwiniętych, mogą nie być w stanie samodzielnie wywiązywać się ze zobowiązań wynikających z tej funkcji.

Na uwagę zasługują także coraz silniej rozprzestrzeniające się ruchy przeciwników pomocy publicznej dla prywatnych instytucji finansowych. W społeczeństwach państw rozwiniętych - choć nie tylko - dominuje przekonanie, że główny strumień pomocy publicznej niesłusznie kierowany jest do ratowania instytucji finansowych, które są zbyt duże, zbyt silnie ze sobą powiązane lub zbyt ważne dla gospodarki,

54 Przykładowo zaangażowanie Niemiec i Francji w pomoc Grecji wynika z faktu, iż z 485 mld dol. długu greckiego na Francję przypada 56,7 mld dol. (z czego ponad $2 / 3$ jest w rękach prywatnych instytucji finansowych, a nieco mniej niż 1/3 w rękach rządu francuskiego), a na Niemcy 33,9 mld dol. (tu proporcje rozkładają się inaczej niż we Francji, czyli nieco ponad 1/3 jest w rękach prywatnych instytucji finansowych, a niecałe $2 / 3$ w rękach rządu niemieckiego). Por. Grecki pożar zduszony, ale jeszcze nie ugaszony, „Gazeta Wyborcza" 2011, 22 lipca, s. 20. 
by upaść, a jednocześnie są głównymi winowajcami zjawisk kryzysowych i obecnej sytuacji. Tym samym fala protestów obejmująca coraz liczniejszą grupę państw może wymusić na ich rządach, jak również na organizacjach międzynarodowych nie tylko modyfikację dotychczasowych koncepcji naprawczych, lecz również w sposób istotny wpłynąć na doktrynalne i systemowe cele, zadania i mechanizmy działalności państwa oraz jego instytucji w układzie globalnym, regionalnym i lokalnym.

\section{The state in contemporary global economy - selected issues}

The 2007+ financial crisis and the depression in real sphere of many economies important for the world economy has led to many initiatives directed against the negative effects of the crisis. The state and its institutions played the most important role in anti-crisis actions. At the beginning states concentrated on fiscal and monetary policy measures aiming to help national economic subjects. In other words, the challenges of early 21 st century changed common opinion on the position and the importance of the modern state. Quickly, however, it has become clear that such help is not sufficient. The advanced level of international cooperation and interdependence between micro- and macroeconomic subjects have led to the situation in which single states could not take effective action against crisis phenomena that were not only initiated in their economies but also imported. In such conditions we can observe the emergence of new international initiatives such as G20, Financial Stability Council, the new European Financial Supervision System or European instruments for financial stability, including the fiscal pact, which was preliminary agreed on during the December summit of the European Council. All those actions are, unfortunately, designed as short-term and emergency measures. They do not aim for longer time frame. There is no debate on doctrinal foundations of the contemporary global economy. The actions described in this text also fit into that pattern, as they are only an attempt at addressing the problems and not an initiative which has pre-dated the contemporary crisis phenomena.

\section{L'État dans l'économie mondiale moderne - certains problèmes}

La crise financière de 2007+ et l'effondrement de nombreuses économies pertinentes à l'ordre économique moderne ont conduit à des initiatives visant à réduire et à prévenir déventuels phénomènes négatifs. Ce sont l'État et ses institutions qui jouaient un rôle majeur. Initialement, les pays ont mis l'accent sur les politiques 
fiscale et monétaire pour aider les entités économiques nationales. Ainsi, les défis posés par le début du XXIe siècle ont changé les attentes envers la position et l'importance de l'État moderne. Cependant, assez rapidement, il s'est avéré que laide proposée n'est pas suffisante.

La nature complexe de la collaboration et de l'interdépendance entre les acteurs au niveau micro- et macro-économique a conduit à une situation dans laquelle certains pays nétaient pas en mesure de contrer efficacement les phénomènes internes et externes se produisant pendant la crise. Dans ces conditions, on observe l'émergence des initiatives internationales telles que le groupe G20, le Conseil de stabilité financière, le nouveau système européen de surveillance financière et les instruments européens pour la stabilité financière, y compris le pacte fiscal initialement déterminé lors du sommet du Conseil européen en décembre. Il est troublant que toutes ces activités sont destinées à un effet temporaire et à court terme. La discussion sur les fondements doctrinaux de l'économie mondiale moderne est nécessaire. Les projets décrits dans cet article s'inscrivent également dans cette tendance. Ils sont une tentative pour répondre à la situation qui a eu lieu et non une initiative, qui a précédé les phénomènes de crise. 